\title{
Fish hatchering and its effects on the morphology of Prochilodus lineatus (Actinopterygii: Prochilodontidae)
}

\author{
S. O. Saraiva ${ }^{a}$ and P. S. Pompeu \\ aLaboratório de Ecologia de Peixes, Setor de Ecologia, Departamento de Biologia, Universidade Federal de \\ Lavras - UFLA, Campus Universitário, CP 3037, CEP 37200- 000, Lavras, MG, Brazil \\ *e-mail: sarahsaraiva@hotmail.com
}

Received: September 8, 2014 - Accepted: January 11, 2015 - Distributed: February 29, 2016

(With 3 figures)

\begin{abstract}
The fish stocking in captivity for later release into natural water bodies has historically been applied in Brazil, as a measure to mitigate impacts caused by dams. However, the released fish are adapted to the hatchery environment, which is totally different from the natural, which results in low post-release survival rates and ineffectiveness of stocking as a management measure. Worldwide, several studies have demonstrated the existence of large phenotypic differences between farmed and wild fish, but in Brazil, there is a great need for this kind of study. Based on this, our objective here was to verify if hatchery fish differ morphologically from its wild counterparties, at the same size class. Hence, a population of young Prochilodus lineatus raised in a fish farming station was compared with another from marginal lagoons of the Grande river. The results indicated that the fish farming resulted in morphologically different individuals of $P$. lineatus and a less diverse population, compared with wild fish. Measures such as environmental enrichment of hatchery tanks should be studied as a way to increase environmental heterogeneity and increase the morphological variability of the fingerlings produced.
\end{abstract}

Keywords: hatchery environment, morphological variability, stocking, released fish, wild fish.

\section{Cultivo em piscicultura e seus efeitos sobre a morfologia de Prochilodus lineatus (Actinopterygii: Prochilodontidae)}

\begin{abstract}
Resumo
A estocagem de peixes em cativeiro para posterior soltura em corpos d'água naturais tem sido historicamente aplicada no Brasil, como medida mitigadora de impactos causados por barramentos. Entretanto, os peixes soltos são adaptados ao ambiente de cultivo que é totalmente diferente do natural, o que resulta em pequenas taxas de sobrevivência pós-soltura e ineficácia das estocagens como medida de manejo. Em escala mundial, diversos estudos já evidenciaram a existência de grandes diferenças fenotípicas entre peixes cultivados e selvagens, mas no Brasil há grande carência de estudos deste tipo. O objetivo do presente estudo foi verificar se peixes cultivados divergem morfologicamente de indivíduos da mesma espécie provenientes de ambiente natural. Para isto, uma população de jovens de Prochilodus lineatus oriunda de uma estação de piscicultura foi comparada com outra da mesma espécie e classe de tamanho oriunda de lagoas marginais do Rio Grande. Os resultados encontrados indicaram que o cultivo em piscicultura resulta em indivíduos de $P$. lineatus morfologicamente diferentes e em uma população menos variada se comparada com os selvagens. Como forma de aumentar a heterogeneidade ambiental e aumentar a variabilidade morfológica dos alevinos produzidos, devem ser estudadas medidas como o enriquecimento ambiental de tanques de piscicultura.
\end{abstract}

Palavras-chave: ambiente de cultivo, variabilidade morfológica, estocagem, peixes cultivados, peixes selvagens.

\section{Introduction}

The Brazilian rivers have been sorely segmented by dams. Fish stocking is one of the management actions used to minimize the impacts of dams on native fish fauna (Agostinho et al., 2008). It consists of the breeding and cultivation of fish in captivity for later release into natural water bodies. It is normally applied when the management goal is to supplement the native populations (Agostinho et al.,
2007). However, despite being historically applied, the efficiency of stocking, as a management measure, has been not satisfactory in Brazil, since the target stocks have not been recovered (Agostinho et al., 2007). This can be explained by poor habitat quality of the stocked rivers (Pompeu, et al., 2012) and by differences between hatchery and wild environment. 
Hatchery tanks are characterized by a high degree of environmental homogeneity (Pakkasmaa et al., 1998). They are normally made of concrete, with no substrate, obstacles or shelter and have constant food availability, high population density and species monoculture. As a result, farmed fish differ from wild fish in several aspects, especially in the morphological ones, exhibiting distinct colorations (Maynard et al., 1995); different body, head and fin proportions (Swain et al., 1991; Fleming et al., 1994; Hard et al., 2000; Solem et al., 2006; Belk et al., 2008) and less morphological variability (Taylor, 1986). Moreover, density-dependent processes probably influence early growth and survival (Winemiller and Dailey, 2002). On the other hand, natural environments are marked by many environmental variations, whether physical, chemical or biological ones. Marginal lagoons inhabited by many neotropical migratory fish species in the early stages of development, are rich in food and shelter provided by aquatic plants, wood debris, and other structures (Agostinho and Júlio-Junior, 1999), and have high species richness with diverse social interactions (Pompeu and Godinho, 2003). As a result of these environmental differences, the survival rates of released fish are low, because they are adapted to the rearing environment and not to the wild (Maynard et al., 1995). The selection of phenotypes adapted to the captivity is called domestication, which can affect the physiology, behavior and morphology of fish (Araki et al., 2008).

Specifically in relation to morphology, polymorphisms between alternative environments may occur in a same species, in response to different selective pressures (Robinson and Wilson, 1996; Langerhans et al., 2003). In this respect, a range of studies conducted, mainly in temperate countries, has demonstrated the existence of wide morphological differences between wild and farmed fish (Taylor, 1986; Swain et al., 1991; Pakkasmaa et al., 1998; Hard et al., 2000; Ojanguren and Brana, 2003; Cramon-Taubadel et al., 2005; Berejikian and Tezak, 2005; Solem et al., 2006; Belk et al., 2008).

Fisheries management in South America has been based on stocking, fisheries regulation and construction of fish passes (Pompeu et al., 2012). However, although fish stocking have been performing for years, we lack basic studies evaluating survival rates of released fish, and the efficiency of this strategy in recovering populations (Vieira and Pompeu, 2001). Until now, there are no studies comparing wild and hatchery fish in respect to morphological aspects. Based on this, the primary goal of this study was to verify if hatchery fish are morphologically different from wild individuals of the same species and size class.

\section{Material and Methods}

\subsection{Species studied}

Prochilodus lineatus (Achille Valenciennes, 1837) (Actinopterygii: Prochilodontidae), popularly known as curimba, curimbatá, curimatã or papa-terra, is a native fish species of the Paraná River Basin. Its feeding habits are detritivorous, eating mostly decaying organic matter (Hahn et al., 2004). Its reproductive habits are migratory, swimming upriver to spawn in the breeding season. The adults inhabit the main channel of the river, showing preference for river stretches surrounded by wetlands (Pesoa and Schulz, 2010). The young inhabit the marginal lagoons of the floodplain, where they remain during the first years of life (Agostinho and Júlio-Júnior, 1999; Graça and Pavanelli, 2007; Pesoa and Schulz, 2010). Prochilodus lineatus was chosen due to its ecological relevance, importance for fishing, and because is one of the most used native fish in stocking and repopulation. It is also used in Brazilian hatchering programs as live food for other native species, mainly piscivores, because of its easy management in pisciculture (Viveiros et al., 2009).

\subsection{Collections}

Hatchery individuals of Prochilodus lineatus were obtained at the hatchery station of Furnas Hidroeletric Plant, located on the Grande river, in Passos county, Minas Gerais state. A total of 62 individuals with standard length ranging from 10.80 to $16.70 \mathrm{~cm}$ were obtained. In this station, fish are produced from wild breeders collected around Furnas reservoir, since its purpose is to perform the repopulation of the areas affected by the dam, including the main tributaries of the reservoir. Fish tanks at the hatchery station have homogeneous conditions, because are made up of concrete walls, characterized by the absence of substrates, barriers or shelters and by high population density, food availability and species monoculture.

Since the aim of this study is compare wild populations with juveniles from hatcheries, wild specimens were captured using gillnets in four marginal lagoons of the Mortes river, a tributary of the Grande river (see Table 1). Floodplain lagoons are considered the main nurseries areas for this species, and the Mortes river is one of the main lotic remnant of the region (Suzuki et al., 2011). The marginal lagoons of this region are rich in food and shelter provided by aquatic plants, twigs and other structures. Exhibits considerable seasonality, provided by variations in hydrological conditions and physicochemical parameters. The lagoons still have high species richness with diverse social interactions (pers. obs.). Collections were conducted during the rainy season of 2011, and a total of 70 individuals were captured, with standard length ranging from 10.99 to $16.57 \mathrm{~cm}$. All fish were sacrificed by overdose of eugenol, fixed in $10 \%$ formalin and preserved in $70 \%$ alcohol. The voucher specimens were deposited in the Ichthyological Collection of The Federal University of Lavras (CI-UFLA 0450 and 0859).

Table 1. Location of marginal lagoons where Prochilodus lineatus individuals were captured.

\begin{tabular}{|c|c|c|c|}
\hline Lagoon & $\begin{array}{c}\text { UTM E } \\
(23 K)\end{array}$ & $\begin{array}{c}\text { UTM N } \\
(23 K)\end{array}$ & County \\
\hline Coqueiros & 545730 & 7667316 & $\begin{array}{l}\text { Conceição da } \\
\text { Barra de Minas }\end{array}$ \\
\hline Capineira & 546924 & 7667772 & $\begin{array}{l}\text { Conceição da } \\
\text { Barra de Minas }\end{array}$ \\
\hline Cavalo & 530741 & 7664408 & Nazareno \\
\hline Canal & 537883 & 7667979 & Nazareno \\
\hline
\end{tabular}




\subsection{Morphometry}

Seventeen morphometric measurements (see Table 2) were taken from each specimen. The linear measurements were obtained directly from the fish body, on the left side, with a digital caliper $(0.01 \mathrm{~mm}$ precision), and drawings of the outline of the body and fins of each fish were made on paper to obtain the body and fin areas. The drawings were then scanned and the areas were calculated using the Image J software (Abramoff et al., 2004). To minimize differences in the measurements due to the specimen size, 12 ecomorphological attributes were calculated (see Table 3 ), which were chosen according to their ecological significance defined in the literature (Hora, 1930; Gatz Junior, 1979; Watson and Balon, 1984; Pouilly et al., 2003).

Ecomorphological attributes are ratios resulting from the division of a morphometric measurement by another, being used from the assumption that this measurements are proportional to each other (Watson and Balon, 1984). To verify the proportionality of the morphometric measurements used, we performed linear regressions between them. All the regressions were positive and significant $(p=0.0001)$, confirming the proportionality between the measurements and allowing to use the ecomorphological attributes resulting from its division.

\subsection{Statistical analysis}

Initially, through the Statistica software, the similarity between the mean standard length of both population (wild and hatchery fish) was confirmed using a $\mathrm{T}$ test. Similar lengths are necessary to enable comparison between the two populations, since there is a dependency between shape and body size (Peres-Neto, 1999). Then, Principal Component Analysis (PCA) was used to evaluate the distribution of individuals in morphological space. To investigate the differences between the populations in the first two PCA axes a $T$ test was conducted and also a Discriminant Analysis (DA), as an alternative test.

Since the tested hypotheses tested are strongly associated with the response of the individual, resulting in a population response, the individuals accounted for the replicates. For each population a normalized Euclidean distance matrix was constructed, in the Past software (Hammer et al., 2001), between the pairs of individuals from the morphological attributes, according to the Equation 1.

$$
D_{j k}=\left[\sum_{i=1}^{n}\left(x_{i j}-x_{j k}\right)^{2}\right]^{\frac{1}{2}}
$$

where $D_{j k}$ is the Euclidean distance between individuals $j$ and $k, n$ is the number of attributes, $x_{i j}$ and $x_{i k}$ are the values of the attribute $i$ for the pair of individuals $j k$.

In the case of normalized distance, the data were adjusted to the Gaussian distribution with average zero and standard deviation one, according to Equation 2.

$x_{i k}^{\prime}=\frac{\left(x_{i k}-\bar{X}_{k}\right)}{D P_{k}}$

where $x_{i k}$ is the average of attribute $k$ of population $i, X_{k}$ the average for all $x_{\mathrm{i} k}$ and $\mathrm{DP}_{K}$, the standard deviation for the attribute $k$.

Table 2. Morphometric measurements and their descriptions.

\begin{tabular}{|c|c|c|c|}
\hline & \multicolumn{3}{|r|}{ Morphometric measurements } \\
\hline & Measurement & Acronym & Description \\
\hline 1. & Standard Length & SL & $\begin{array}{l}\text { Distance from tip of the snout to the posterior margin of caudal } \\
\text { peduncle }\end{array}$ \\
\hline 2. & Body Height & $\mathrm{BH}$ & $\begin{array}{l}\text { Greatest dorsal-ventral distance perpendicular to the longest body } \\
\text { axis }\end{array}$ \\
\hline 3. & Body Width & BW & Greatest side to side body width \\
\hline 4. & Average Body Height & $\mathrm{ABH}$ & $\begin{array}{l}\text { Distance from the abdomen to the line that cuts the body between } \\
\text { the mouth and the tail }\end{array}$ \\
\hline 5. & Body Area & BA & Body area plus the area of the caudal fin \\
\hline 6. & Head Length & HL & Distance between the tip of the snout to the end of the operculum \\
\hline 7. & Head Height & $\mathrm{HH}$ & $\begin{array}{l}\text { Distance between the dorsal and ventral part of the head in the } \\
\text { region of the eyes }\end{array}$ \\
\hline 8. & Eye Height & EH & Distance from the center of the eye to the lower jaw \\
\hline 9. & Caudal Peduncle Length & CPL & Distance between the end of the anal fin to the top of the caudal \\
\hline 10 . & Caudal Peduncle Height & $\mathrm{CPH}$ & Height of peduncle measured at the same point as the width \\
\hline 11. & Caudal Peduncle Width & CPW & Peduncle width measured at its midpoint \\
\hline 12. & Caudal Fin Width & CFW & Maximum distance between the two ends of the fin fully extended \\
\hline 13. & Caudal Fin Area & CFA & Fully extended Caudal fin area \\
\hline 14. & Pelvic Fin Area & PIFA & Fully extended pelvic fin area \\
\hline 15 . & Pectoral Fin Length & PtFL & Distance between the base of the fin and its end \\
\hline 16. & Pectoral Fin Width & PtFW & $\begin{array}{l}\text { Largest width of the fin in a plane perpendicular to the length axis } \\
\text { of the fin fully open }\end{array}$ \\
\hline 17. & Pectoral Fin Area & PtFA & Fully extended Pectoral fin area \\
\hline
\end{tabular}


Table 3. Descriptions of ecomorphological attributes and their ecological significance.

\section{Ecomorphological attributes}

\begin{tabular}{|c|c|c|c|}
\hline & Attribute & Formula & Significance \\
\hline 1. & Compression Index & $\mathrm{CI}=\mathrm{BH} / \mathrm{BW}$ & $\begin{array}{l}\text { Higher values indicate laterally compressed fish that } \\
\text { inhabit areas of low water velocity (Watson and Balon, } \\
\text { 1984). }\end{array}$ \\
\hline 2. & $\begin{array}{l}\text { Ventral flattening } \\
\text { Index }\end{array}$ & $\mathrm{VFI}=\mathrm{ABH} / \mathrm{BH}$ & $\begin{array}{l}\text { Low values are typical of fish living in waters with } \\
\text { high speed, enabling it to maintain its position without } \\
\text { swimming (Hora, 1930). }\end{array}$ \\
\hline 3. & $\begin{array}{l}\text { Relative height of the } \\
\text { body }\end{array}$ & $\mathrm{RH}=\mathrm{BH} / \mathrm{SL}$ & $\begin{array}{l}\text { Inversely related to the speed of the water and directly } \\
\text { related to the ability to develop vertical displacements } \\
\text { (Gatz Junior, 1979). }\end{array}$ \\
\hline 4. & $\begin{array}{l}\text { Relative position of } \\
\text { the eye }\end{array}$ & $\mathrm{RPE}=\mathrm{EH} / \mathrm{HH}$ & $\begin{array}{l}\text { This index is related to food detection and provides } \\
\text { information about the use of vision in predation activities } \\
\text { (Pouilly et al., 2003). It is indicative of the preferred } \\
\text { position in the water column (Gatz Junior, 1979). }\end{array}$ \\
\hline 5. & $\begin{array}{l}\text { Relative length of the } \\
\text { head }\end{array}$ & $\mathrm{RLH}=\mathrm{HL} / \mathrm{SL}$ & $\begin{array}{l}\text { Directly related to the size of the prey, high values suggest } \\
\text { species which are predators of relatively large prey (Gatz } \\
\text { Junior, 1979). }\end{array}$ \\
\hline 6. & $\begin{array}{l}\text { Relative length of the } \\
\text { caudal peduncle }\end{array}$ & $\mathrm{RLCP}=\mathrm{CPL} / \mathrm{SL}$ & $\begin{array}{l}\text { Relatively long peduncles indicate fish that inhabit } \\
\text { turbulent waters and have good swimming skills (Gatz } \\
\text { Junior, 1979; Watson and Balon, 1984). }\end{array}$ \\
\hline 7. & $\begin{array}{l}\text { Compression Index of } \\
\text { the caudal peduncle }\end{array}$ & $\mathrm{CICP}=\mathrm{CPH} / \mathrm{CPW}$ & $\begin{array}{l}\text { It is inversely related to the amplitude of the swimming } \\
\text { movements, higher values indicate compressed peduncles, } \\
\text { typical of less active swimmers (Gatz Junior, 1979). }\end{array}$ \\
\hline 8. & $\begin{array}{l}\text { Relative area of the } \\
\text { caudal fin }\end{array}$ & $\mathrm{RACdF}=\mathrm{CdFA} / \mathrm{BA}$ & $\begin{array}{l}\text { High values indicate fins capable of producing rapid } \\
\text { pulses, typical for swimming of many benthic fish } \\
\text { (Watson and Balon, 1984); }\end{array}$ \\
\hline 9. & $\begin{array}{l}\text { Aspect ratio of the } \\
\text { caudal fin }\end{array}$ & $\mathrm{ARCdF}=\mathrm{CdFW} / \mathrm{CdFA}$ & $\begin{array}{l}\text { Directly proportional to the amount of swimming that the } \\
\text { fish conducts (Gatz Junior, 1979). }\end{array}$ \\
\hline 10. & $\begin{array}{l}\text { Relative area of the } \\
\text { pelvic fin }\end{array}$ & $\mathrm{RAPIF}=\mathrm{PIFA} / \mathrm{BA}$ & $\begin{array}{l}\text { Benthic fish have relatively large areas (Gatz Junior, } \\
\text { 1979). }\end{array}$ \\
\hline 11. & $\begin{array}{l}\text { Relative area of the } \\
\text { pectoral fin }\end{array}$ & $\mathrm{RAPtF}=\mathrm{PtFA} / \mathrm{BA}$ & $\begin{array}{l}\text { Higher values indicate slower swimmers who use these } \\
\text { fins to perform maneuvers. However, fish inhabitants } \\
\text { of fast water that use them as water deflection surfaces, } \\
\text { keeping their body close to the substrate, also have high } \\
\text { values (Watson and Balon, 1984). }\end{array}$ \\
\hline 12. & $\begin{array}{l}\text { Aspect ratio of the } \\
\text { pectoral fin }\end{array}$ & $\mathrm{ARPtF}=\mathrm{PtFL} / \mathrm{PtFW}$ & $\begin{array}{l}\text { High values indicate long fins and suggest fish with great } \\
\text { swimming ability (Watson and Balon, 1984). }\end{array}$ \\
\hline
\end{tabular}

From each distance matrix were calculated: the distance of the closest neighbor (DCN), as a dispersion index of individuals in ecomorphological space (Ricklefs et al., 1981); and the distance to the centroid of each individual of the population (DC), as an estimate of the relative size of the morphological hypervolume occupied by the population (Winemiller, 1991).

To evaluate possible differences between the distance from the centroid and the closest neighbor we applied an averages test, through the Statistica software. The data of the distance from the centroid were normalized by logarithmization in base ten and tested by the $\mathrm{T}$ test. The data of the distance from the closest neighbor could not be normalized and thus the nonparametric Kruskal-Wallis test was used.

\section{Results}

The analyzed fish of wild and hatchery populations showed a similar standard length $(\mathrm{t}(1 ; 131)=0.1441$; $p=0.7048$ ), allowing comparison between the two groups.

The Principal Component Analysis (PCA) indicated that each population occupies completely distinct morphological spaces (see Figure 1). The first two PCA axes were the most important in explaining the total variation of the sample $(\mathrm{PCA} 1=34.73 \%$ and $\mathrm{PCA} 2=12.08 \%)$, jointly explaining $46.81 \%$ of variance existing between the two populations and due to the ecomorphological attributes analyzed.

The $\mathrm{T}$ test conducted between the scores of the first two PCA axes showed significant differences only for the first axis (PCA 1: $\mathrm{p}=0.0001 ; \mathrm{MS}=453.7531 ; \mathrm{t}=640.2777$; 
Projection of the cases on the factor-plane $\left(\begin{array}{ll}1 \times & 2\end{array}\right)$

Cases with sum of cosine square $>=0.00$

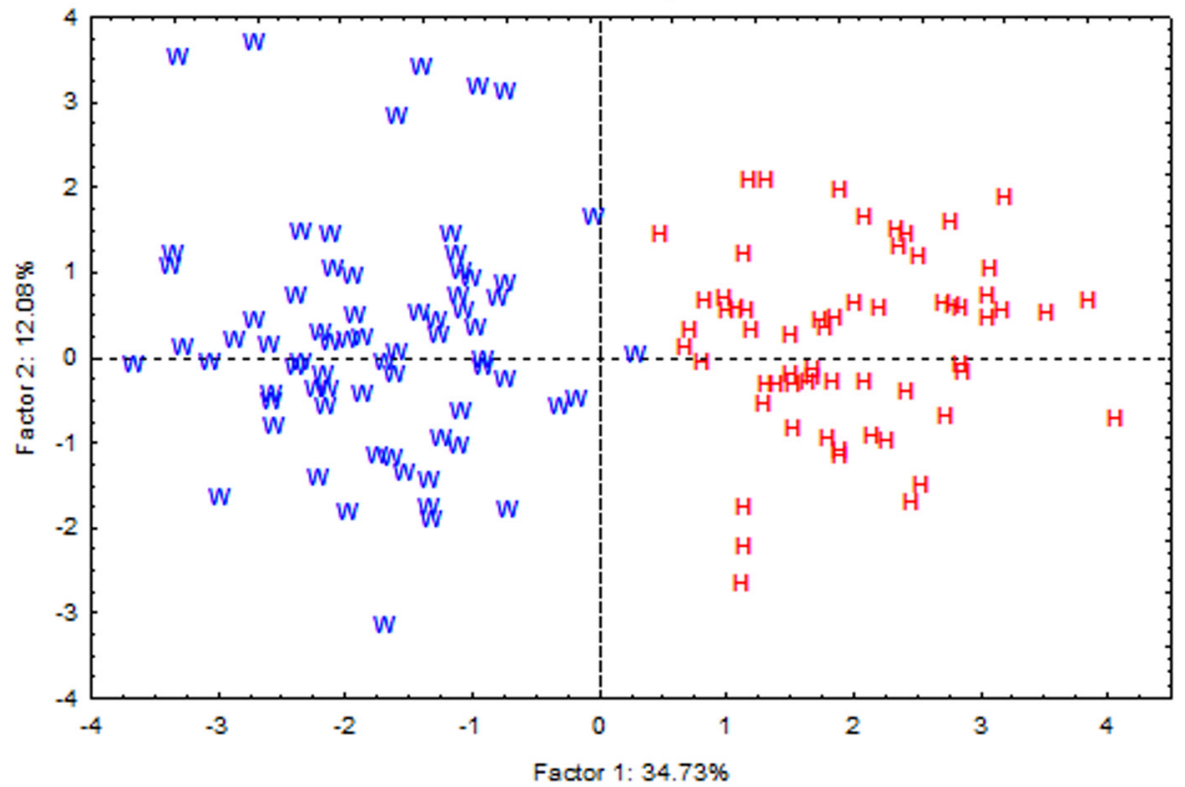

Figure 1. Projection of two populations of Prochilodus lineatus $[\mathrm{H}=$ hatchery; $\mathrm{W}=$ wild $]$ in the first two axes of the Principal Component Analysis.

PCA 2: $\mathrm{p}=0.9113 ; \mathrm{MS}=0.0181 ; \mathrm{t}=0.0124)$. Thus, the ecomorphological attributes that more contributed to the differentiation between populations in the first axis of the PCA, make up the main source of morphological differentiation among populations. The most important attributes in PCA 1 (considering contributions higher than $70 \%$ ) were compression index (CI), relative body height $(\mathrm{RH})$, relative area of the pelvic fin (RAPIF) and aspect ratio of the caudal fin (ARCdF).

The discriminant analysis was also significant between the two analyzed populations (Wilks' Lambda: 0.10259; $\mathrm{F}(12,119)=86.748 \mathrm{p}=0.0001)$. The ecomorphological attributes that contributed significantly to the differentiation between them were relative height $(\mathrm{RH})(\mathrm{F}(3,176)=72.03539$, $\mathrm{p}=0.00000)$, compression index of the caudal peduncle $(\mathrm{CICP})(\mathrm{F}(3,176)=17.33353, \mathrm{p}=0.00006)$, relative area of the pectoral fin $(\mathrm{RAPtF})(\mathrm{F}(3,176)=17.22258$, $\mathrm{p}=0.00006)$, aspect ratio of the caudal fin (ARCdF) $(\mathrm{F}(3,176)=6.37739, \mathrm{p}=0.01287)$ and relative length of the head $(\mathrm{RLH})(\mathrm{F}(3,176)=4.76763, \mathrm{p}=0.03096)$ (see Table 4).

Considering the attributes individually, all the important ones to the differentiation in PCA, as well as in the DA analysis performed, were significantly different between wild and hatchery fish (Wilks' Lambda: 0.10259; F (12,119) $=86.748 ; \mathrm{p}=0.0001)$. Two attributes, RH and ARCdF, were pointed out by the two analyses as the most important. These two attributes showed higher values for the wild population, indicating that the wild fish had a higher body $(\mathrm{RH}: \mathrm{KW}(1 ; 132)=97.71758, \mathrm{p}=0.0001)$ and larger caudal fin $(\mathrm{ARCdF}: \mathrm{t}(1 ; 130)=90.4828, \mathrm{p}=0.0001)$ (see Figure 2).
Table 4. Discriminant analysis between wild and hatchery populations.

\begin{tabular}{lrc}
\hline \multirow{2}{*}{ Attributes } & \multicolumn{2}{c}{ Prochilodus lineatus } \\
\cline { 2 - 3 } & F (3,176) & p Value \\
\hline CI & 0.64579 & 0.423226 \\
RH & $\mathbf{7 2 . 0 3 5 3 9}$ & $\mathbf{0 . 0 0 0 0 0 0}$ \\
RLCP & 0.00026 & 0.987277 \\
CICP & $\mathbf{1 7 . 3 3 3 5 3}$ & $\mathbf{0 . 0 0 0 0 6 0}$ \\
VFI & 0.54897 & 0.460200 \\
RAPtF & $\mathbf{1 7 . 2 2 2 5 8}$ & $\mathbf{0 . 0 0 0 0 6 3}$ \\
ARPtF & 3.36385 & 0.069141 \\
RAPIF & 0.55145 & 0.459190 \\
RACdF & 1.96947 & 0.163108 \\
ARCdF & $\mathbf{6 . 3 7 7 3 9}$ & $\mathbf{0 . 0 1 2 8 7 3}$ \\
RPE & 0.64820 & 0.422364 \\
RLH & $\mathbf{4 . 7 6 7 6 3}$ & $\mathbf{0 . 0 3 0 9 6 2}$ \\
\hline
\end{tabular}

(Wilks' Lambda: 0.10259, F $(12,119)=86.748 \mathrm{p}=0.0001$ ). The attributes in bold were those that best contributed to discrimination.

The morphological variability of the fish was analyzed by comparing the distance from the centroid and closest neighbor (see Figure 3). The morphological variability of the wild population was higher than that of the hatchery population, because the wild fish presented higher dispersion in morphological space (ANOVA $\log (\mathrm{DC}+1)$ : $\mathrm{F}(1 ; 131)=11.9207, \mathrm{p}=0.0007)$ and thus occupied a larger morphological hypervolume (Kruskal-wallis' test CDN: $\operatorname{KW}(1 ; 133)=18.7552 ; \mathrm{p}=0.0001)$. 

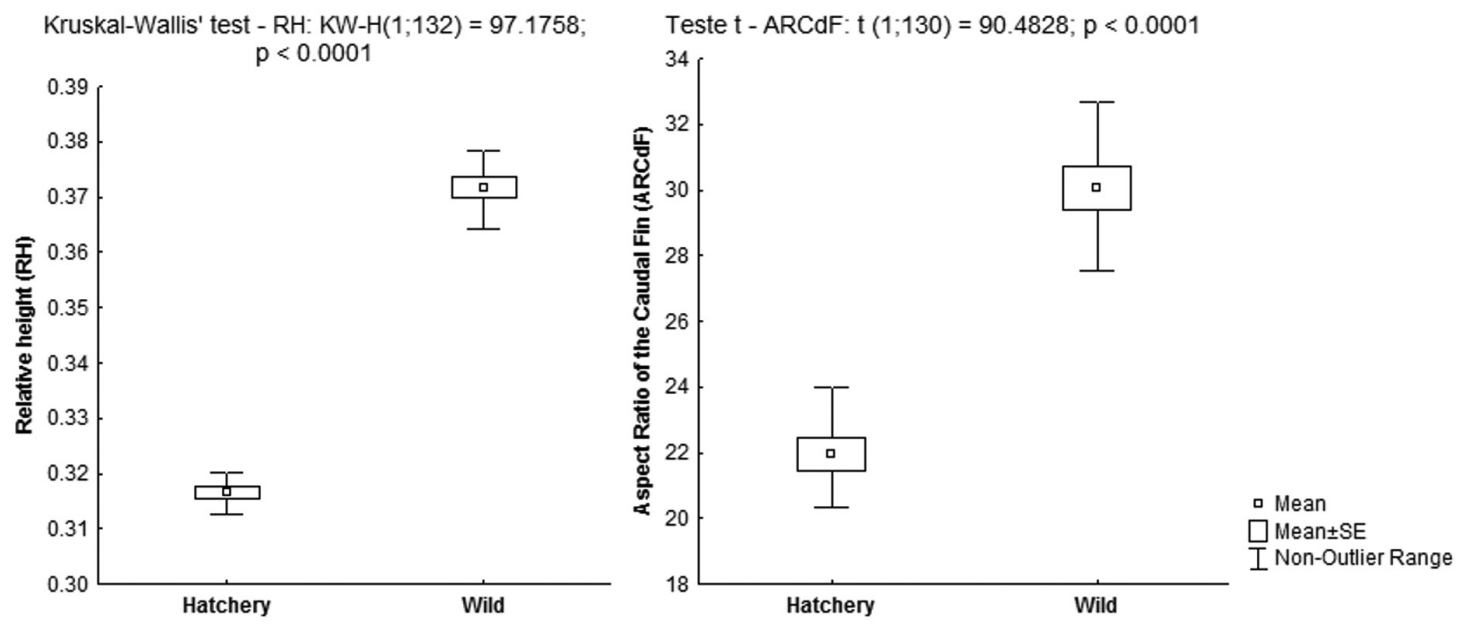

Figure 2. Most important ecomorphological attributes in morphological differentiation between populations of Prochilodus lineatus in PCA1 and DA concomitantly.
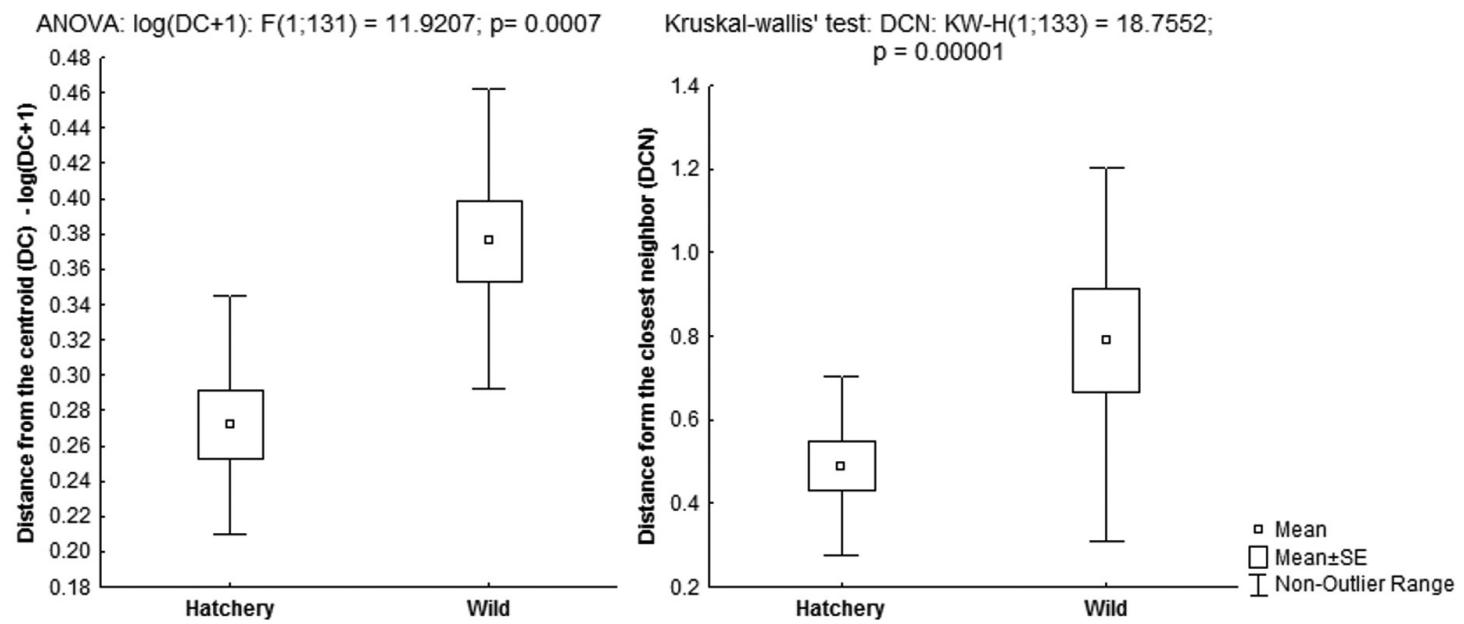

Figure 3. Log of the distance from the centroid plus one $[\log (\mathrm{DC}+1)]$ and the distance from the closest neighbor. The ANOVA performed for the distance from the centroid was significantly higher for the population of wild fish, as was the Kruskal-Wallis test conducted for the distance from the nearest neighbor.

\section{Discussion}

The results show that the fish hatcheries creates a less diverse population and individuals morphologically different from its wild counterparties of the same size class. Selective pressures present in the fish farming tank are quite different from those existing in the natural environment, which may result in very different morphologies generated by phenotypic plasticity (Taylor, 1986; Swain et al., 1991; Fleming et al., 1994; Hard et al., 2000; Belk et al., 2008). Therefore, in the present study, the morphological differences between wild and hatchery fish could have been generated by phenotypic plasticity caused by adaptation to the growth environment, or may have been caused by genetic differences between populations.

The absence of genetic data does not allow separating the effects of these two sources of variation. But as the hatchery population also has a wild origin, it is concluded that the morphological differences detected were mostly due to the environmental component. One evidence of this, it is that the differentiation between the two studied populations can be easily understood considering the environmental differences between the lagoons and hatchery tanks. For example, the relative body height $(\mathrm{RH})$ was higher for wild fish. This attribute is directly related to the ability of the fish to develop vertical displacements (Gatz Junior, 1979). Therefore, the higher RH of wild fish is consistent with the need to perform maneuvers to avoid obstacles, considering the structural richness of the lagoons. Wild fish also had higher aspect ratio of the caudal fin (ARCdF), attribute that is directly proportional to the amount of swimming that the fish does (Gatz Junior, 1979). This can be an indication that wild fish swim more 
than the hatchery, probably because they have a larger and more complex environment to explore. Morphological differences between populations of wild and hatchery fish have been previously highlighted, and environmental factors have been suggested as the principal source of variation (Taylor, 1986; Fleming et al., 1994; Ellis et al., 1997; Cramon-Taubadel et al., 2005; Belk et al., 2008). However, the role of intraspecific interactions in wild environments as a morphological differentiation mechanism cannot be excluded. During interspecific competition, for instance, individuals from one species suffer a reduction in fertility, growth or survival as a result of resource exploitation or interference by another species (Begon et al. 2007).

In relation to the morphological variability, the explanation for the lower value found for the hatchery population may lie in the lower genetic variability of this population (Vuorinen, 1982; Agostinho et al., 2007), which may consequently result in minor morphological variability. However, recent studies (Gomes et al., 2008; Chittenden et al., 2010) have shown the presence of minor genetic differences when comparing wild specimens with hatchery, since currently genetic diversity of stocked fish has been expanded from the use of a high number of breeder individuals of wild origin. Thus, the low morphological variability found for the hatchery population likely is due to the high homogeneity of the tanks (Hynes et al., 1981; Taylor, 1986), where environmental pressures are constant, due to low disturbance frequency. The intraspecific polymorphism is typically caused by different selective pressures (Langerhans et al., 2003). Thus, in heterogeneous environments such as lagoons, subject to numerous pressures and disturbances, various morphological types can coexist, as each may be favored at different times, depending on the disorder or pressure acting on the population. On the other hand, in homogeneous environments, such as farming tanks, the constant selective pressure favors a basic type of morphology, so that individuals tend to be morphologically closer.

Although stocking is intended to replenish stocks that have experienced genetic and/or demographic losses, the can carry environmental risks, even when performed with native species. These potential impacts include dissemination of pathogens and parasites and deleterious effects related to the genetic quality of matrices and fingerlings (bottleneck effects, loss of genetic variability and fitness, domestication) (Agostinho et al., 2010). The release of a less variable and morphologically distinct population does not represent itself an impact. However, these aspects must represent lower probability to survive, hindering the use of this strategy as a conservation tool.

In summary, our results demonstrate that hatchery populations of Prochilodus lineatus are morphologically different and less diverse when compared with wild ones. However, for the actual consequences for hatchery management it is necessary to carry out specific experiments and studies that aim to elucidate how much and for how long these morphological differences could affect performance and survival of fish released in the natural environment. Additionally, considering the lower morphological variability of hatchery populations and the concept of environmental heterogeneity, the enrichment of hatchery tanks can be proposed as a way of increasing the morphological variability of the produced fingerlings.

\section{Acknowledgements}

We thank Furnas for having provided the farmed fish and Dr. Fábio Mineo Suzuki for the wild fish. PSP was awarded a researched productivity grant (CNPq 306325/2011-0) and a Minas Gerais scholarship grant (FAPEMIG PPM 00237/13).

\section{References}

ABRAMOFF, M.D., MAGALHÃES, P.J. and RAM, S.J., 2004. Image Processing with ImageJ. Biophotonics International, vol. 11 , no. 7 , pp. 36-42.

AGOSTINHO, A.A. and JÚLIO-JUNIOR, H.F., 1999. Peixes da bacia do alto Paraná. In: R.H. LOWE-MCCONNELL. Estudos ecológicos de comunidades de peixes tropicais. São Paulo: EDUS, pp. 374-400.

AGOSTINHO, A.A., GOMES, L.C. and PELICICE, F.M., 2007. Ecologia e manejo de recursos pesqueiros em reservatórios do Brasil. Maringá: Universidade Estadual de Maringá.

AGOSTINHO, A.A., PELICICE, F.M. and GOMES, L.C., 2008. Dams and the fish fauna of the Neotropical region: impacts and management related to diversity and fisheries. Brazilian Journal of Biology $=$ Revista Brasileira de Biologia, vol. 68, no. 4, suppl., pp. 1119-1132. http://dx.doi.org/10.1590/S151969842008000500019. PMid:19197482.

AGOSTINHO, A.A., PELICICE, F.M., GOMES, L.C. and JÚLIO-JUNIOR, H.F., 2010. Reservoir fish stocking: when one plus one may be less than two. Natureza \& Conservação, vol. 08, no. 2, pp. 103-111. http://dx.doi.org/10.4322/natcon.00802001.

ARAKI, H., BEREJIKIAN, B.A., FORD, M.J. and BLOUIN, M.S., 2008. Fitness of hatchery-hatchery salmonids in the wild. Evolutionary Applications, vol. 1, no. 2, pp. 342-355. http:// dx.doi.org/10.1111/j.1752-4571.2008.00026.x. PMid:25567636.

BEGON, M., TOWNSEND, C.R. and HARPER, J.L., 2007. Ecologia de indivíduos e ecossistemas. São Paulo: Artmed.

BELK, M.C., BENSON, L.J., RASMUSSEN, J. and PECK, S.L., 2008. Hatchery-induced morphological variation in an endangered fish: a challenge for hatchery-based recovery efforts. Canadian Journal of Fisheries and Aquatic Sciences, vol. 65, no. 3, pp. 401-408. http://dx.doi.org/10.1139/f07-176.

BEREJIKIAN, B. and TEZAK, P., 2005. Rearing in enriched hatchery tanks improves dorsal fin quality of juvenile steelhead. North American Journal of Aquaculture, vol. 67, no. 4, pp. 289293. http://dx.doi.org/10.1577/A05-002.1.

CHITTENDEN, C.M., BIAGI, C.A., DAVIDSEN, J.G., DAVIDSEN, A.G., KONDO, H., MCKNIGHT, A., PEDERSEN, O.P., RAVEN, P.A., RIKARDSEN, A.H., SHRIMPTON, J.M., ZUEHLKE, B., MCKINLEY, R.S. and DEVLIN, R.H., 2010. Genetic versus rearing-environment effects on phenotype: hatchery and natural rearing effects on hatchery- and wild-born coho salmon. PLoS 
One, vol. 5, no. 8, pp. e12261. http://dx.doi.org/10.1371/journal. pone.0012261. PMid:20808853.

CRAMON-TAUBADEL, N., LING, E.N., COTTER, D. and WILKINS, N.P., 2005. Determination of body shape variation in Irish hatchery-hatchery and wild Atlantic salmon. Journal of Fish Biology, vol. 66, no. 5, pp. 1471-1482. http://dx.doi. org/10.1111/j.0022-1112.2005.00698.x.

ELLIS, T., HOWELL, B.R. and HAYES, J., 1997. Morphological differences between wild and hatchery-reared turbot. Journal of Fish Biology, vol. 50, no. 5, pp. 1124-1128. http://dx.doi. org/10.1111/j.1095-8649.1997.tb01637.x.

FLEMING, I.A., JONSSON, B. and GROSS, M.R., 1994. Phenotypic divergence of sea-ranched, farmed, and wild salmon. Canadian Journal of Fisheries and Aquatic Sciences, vol. 51, no. 12, pp. 2808-2824. http://dx.doi.org/10.1139/f94-280.

GATZ JUNIOR, A.J., 1979. Ecological morphology of freshwater stream fishes. Tulanne Studies in Zoology Botany, vol. 21, pp. 91-124.

GOMES, P.C., RIBEIRO, R.P., BARRERO, N.L., POVH, J.A., VARGAS, L. and SIROL, R.N., 2008. Diversidade genética de três estoques de piapara (Leporinus elongatus), utilizando RAPD. Acta Scientiarum Animal Sciences, vol. 30, no. 2, pp. 241-247. http://dx.doi.org/10.4025/actascianimsci.v30i2.4710.

GRAÇA, W.J. and PAVANELLI, C.S., 2007. Peixes da planície de inundação do alto rio Paraná e áreas adjacentes. Maringá: Eduem. 241 p.

HAHN, N.S., FUGI, R. and ANDRIAN, I.F., 2004. Trophic ecology of the fish assemblages. In: S.M. THOMAZ, A.A. AGOSTINHO and N.S. HAHN. The Upper Paraná River and its floodplain: physical aspects, ecology and conservation. Leiden: Backhuys Publishers, pp. 247-269.

HAMMER, Ø., HARPER, D.A.T. and RYAN, P.D., 2001. PAST: paleontological statistics software package for education and data analysis. Palaeontologia Electronica, vol. 4, no. 1, pp. 9.

HARD, J.J., BEREJIKIAN, B.A., TEZAK, E.P., SCHRODER, S.L., KNUDSEN, C.M. and PARKER, L.T., 2000. Evidence for morphometric differentiation of wild and captively hatchery adult coho salmon: a geometric analysis. Environmental Biology of Fishes, vol. 58, no. 1, pp. 61-73. http://dx.doi.org/10.1023/A:1007646332666.

HORA, S.L., 1930. Ecology, bionomics and evolution of the torrential fauna, with special reference to the organs of attachment. Philosophical Transactions of the Royal Society of London, vol. 218, no. 450-461, pp. 171-282. http://dx.doi.org/10.1098/ rstb.1930.0005.

HYNES, J.D., BROWN, E.H. Jr., HELLE, J.H., RYMAN, N. and WEBSTER, D.A., 1981. Guidelines for the culture of fish stocks for resource management. Canadian Journal of Fisheries and Aquatic Sciences, vol. 38, no. 12, pp. 1867-1876. http://dx.doi. org/10.1139/f81-232.

LANGERHANS, R.B., LAYMAN, C.A., LANGERHANS, A.K. and DEWITT, T.J., 2003. Habitat associated morphological divergence in two neotropical fish species. Biological Journal of the Linnean Society, vol. 80, no. 4, pp. 689-698. http://dx.doi. org/10.1111/j.1095-8312.2003.00266.x.

MAYNARD, D.J., FLAGG, T.A. and MAHNKEN, C.V.W., 1995. A review of seminatural culture strategies for enhancing the postrelease survival of anadromous salmonids. Seattle: National Marine Fisheries Service.
OJANGUREN, A.F. and BRANA, F., 2003. Effects of size and morphology on swimming performance in juvenile brown trout (Salmo trutta L.). Ecology Freshwater Fish, vol. 12, no. 4, pp. 241-246. http://dx.doi.org/10.1046/j.1600-0633.2003.00016.x.

PAKKASMAA, S., RANTA, E. and PIIRONEN, J., 1998. A morphometric study on four land-locked salmonid species. Annales Zoologici Fennici, vol. 35, no. 3, pp. 131-140.

PERES NETO, P.R., 1999. Alguns métodos e estudos em Ecomorfologia de peixes de riacho. In: E.P. CARAMASCHI, R. MAZZONI and P.R. PERES-NETO. Ecologia de peixes de riachos. Rio de Janeiro: Pós-Graduação em Educação da Universidade Federal do Rio de Janeiro, pp. 209-236.

PESOA, N.A. and SCHULZ, U.H., 2010. Diel and seasonal movements of grumatã Prochilodus lineatus (Valenciennes 1836) (Characiformes: Prochilodontidae) in the Sinos River, Southern Brazil. Brazilian Journal of Biology $=$ Revista Brasileira de Biologia, vol. 70, no. 4, suppl., pp. 1169-1177. http://dx.doi. org/10.1590/S1519-69842010000600006. PMid:21225158.

POMPEU, P.S. and GODINHO, H.P., 2003. Ictiofauna de três lagoas marginais do médio São Francisco. In: H.P. GODINHO and A.L. GODINHO. Águas, peixes e pescadores do São Francisco das Minas Gerais. Belo Horizonte: PUC Minas, pp. 167-181.

POMPEU, P.S., AGOSTINHO, A.A. and PELICICE, F.M., 2012. Existing and future challenges: the concept of successful fish passage in South America. River Research and Applications, vol. 28 , no. 4 , pp. 504-512. http://dx.doi.org/10.1002/rra.1557.

POUILLY, M., LINO, F., BRETENOUX, J.G. and ROSALES, C., 2003. Dietary morphological relationships in a fish assemblage of the Bolivian Amazonian floodplain. Journal of Fish Biology, vol. 62, no. 5, pp. 1137-1158. http://dx.doi.org/10.1046/j.10958649.2003.00108.x.

RICKLEFS, R.E., COCHRAN, D. and PIANKA, E.R., 1981. A morphological analysis of the sctruture of communities of lizards in desert habitats. Ecology, vol. 62, no. 6, pp. 1474-1483. http:// dx.doi.org/10.2307/1941504.

ROBINSON, B.W. and WILSON, D.S., 1996. Genetic variation and phenotypic plasticity in a trophically polymorphic population ofpumpkinseed sunfish (Lepomis gibbosus). Evolutionary Ecology, vol. 10, no. 6, pp. 631-652. http://dx.doi.org/10.1007/BF01237711.

SOLEM, Ø., BERG, O.K. and KJØSNES, A.J., 2006. Inter- and intra-population morphological differences between wild and farmed Atlantic salmon juveniles. Journal of Fish Biology, vol. 69 , no. 5, pp. 1466-1481. http://dx.doi.org/10.1111/j.10958649.2006.01208.x

SUZUKI, F.M., PIRES, L.V. and POMPEU, P.S., 2011. Passage of fish larvae and eggs through the Funil, Itutinga and Camargos Reservoirs on the upper Rio Grande (Minas Gerais, Brazil). Neotropical Ichthyology, vol. 9, no. 3, pp. 617-622. http://dx.doi. org/10.1590/S1679-62252011000300014.

SWAIN, D.P., RIDDELL, B.E. and MURRAY, C.B., 1991. Morphological differences between hatchery and wild populations of coho salmon (Oncorhynchus kisutch): environmental versus genetic origin. Canadian Journal of Fisheries and Aquatic Sciences, vol. 48, no. 9, pp. 1783-1791. http://dx.doi.org/10.1139/f91-210.

TAYLOR, E.B., 1986. Differences in morphology between wild and hatchery populations of juvenile Coho Salmon. Progressive Fish-Culturist, vol. 48, no. 3, pp. 171-176. http://dx.doi. org/10.1577/1548-8640(1986)48<171:DIMBWA>2.0.CO;2.

VIEIRA, F. and POMPEU, P.S., 2001. Peixamentos: uma alternativa eficiente? Ciência Hoje, vol. 30, no. 175, pp. 28-33. 
VIVEIROS, A.T.M., ÓRFÃO, L.H., MARIA, A.N. and ALLAMAN, I.B., 2009. A simple, inexpensive and successful freezing method for Curimba Prochilodus lineatus (Characiformes) semen. Animal Reproduction Science, vol. 112, no. 3-4, pp. 293-300. http:// dx.doi.org/10.1016/j.anireprosci.2008.04.025. PMid:18524505.

VUORINEN, J., 1982. Little genetic variation in the Finnish Lake salmon, Salmo salar sebago (Girard). Hereditas, vol. 97, no. 2, pp. 189-192. http://dx.doi.org/10.1111/j.1601-5223.1982.tb00762.x.

WATSON, D.J. and BALON, E., 1984. Ecomorphological analysis of taxocenes in rainforest streams of northern Borneo.
Journal of Fish Biology, vol. 25, no. 3, pp. 371-384. http://dx.doi. org/10.1111/j.1095-8649.1984.tb04885.x.

WINEMILLER, K.O., 1991. Ecomorphological diversification in lowland freshwater fish assemblages from five biotic regions. Ecological Monographs, vol. 61, no. 4, pp. 343-365. http://dx.doi. org/10.2307/2937046.

WINEMILLER, K.O. and DAILEY, W.H., 2002. Life history strategies and population regulation: theory predicts consequences for supplemental stocking of tarpon. Contributions in Marine Science, vol. 35, pp. 81-94. 